\title{
Medical Care, Freedom of Religion, and Mitigation of Damages
}

The courts have never satisfactorily resolved whether a plaintiff in a tort action who disapproves of medical care on religious grounds may be required to obtain such care in mitigation of damages. This issue has arisen in numerous cases over the years, and reference to it has been a standard feature in torts textbooks. ${ }^{1}$ This Note attempts to resolve this issue by examining the two positions adopted by courts in the past and by indicating how a third alternative is required by recent First Amendment case law.

The mitigation of damages doctrine imposes a duty on a potential tort plaintiff to make a reasonable attempt after an accident to reduce his injuries. It denies compensation for additional damages attributable to a failure to fulfill that duty. ${ }^{2}$ A constitutional issue arises when a plaintiff has religious beliefs about the proper ways to cure injuries. Christian Scientists and many Pentecostal groups teach that all physical maladies may be cured spiritually." Jehovah's Witnesses generally accept medical care, but believe it is a grave sin to accept blood transfusions even in a life-and-death situation. ${ }^{4}$ Unless the mitigation

1. E.g., P. Keeton \& R. Keeton, Cases and Materials on the Law of Torts 192 (1971); H. Shulman, F. James \& O. Gray, Cases and Materials on the Law of Torts 474-76 (3d ed. 1976).

2. 2 F. Harper \& F. James, The LAw of Torts $\$ 22.10$, at 1231-32 (1956); W. Prosser, HANDBOOK OF THE LAw OF TORTS $\S 65$, at $422-24$ (4th ed. 1971). In essence, the doctrine, also known as the "avoidable consequences" rule, $i d$., creates a form of plaintiff's negligence, $i d$. This is not, however, a comparative negligence rule. The plaintiff is barred from recovery for all damages caused in part by his unreasonable actions. 2 F. HARPER \& F. JAMEs, supra $\$ 22.10$, at 1232 . Nor is it, of course, a contributory negligence rule, because the defendant remains liable for injuries that could not have been mitigated. W. Prosser, supra $\$ 65$, at 423 .

3. See M. Eddy, Science ANd Health 142-64 (1937) (through Christian Science, "divine Mind" cures all ailments); Yearbook of American and Canadian Churches 42, 45-46, 78 (C. Jacquet ed. 1977) (Pentecostal faith-healing groups include Church of God, Church of God of Prophecy, and Pentecostal Free Will Baptist Church). Christian Science does not absolutely prohibit medical care. Members are taught that all diseases can and should be cured by faith healing, and those who seek medical care are said to have had lapses of faith, rather than to have committed sins. D. John, The Christian ScIence Way of Life 127-29 (1962). But it is also taught that the two healing methods are fundamentally incompatible and cannot be combined. Id. Thus a law requiring medical care would substantially interfere with the practice of the Christian Science faith. $I d$. at 19. See Committee on Publication, legal Rights and Obligations of Christian Scientists in Connecticut 14 (1975) (law compelling Christian Scientist to submit to medical treatment amounts to limiting his worship of God by governmental decree).

4. The Jehovah's Witnesses no longer adhere to their earlier belief in faith healing. H. Stroup, The Jehovah's Witnesses 107 (1945), but they now refuse blood transfusions regularly, because they believe them to be specifically prohibited by the Bible. A. 
rule is applied in a way that accommodates the beliefs of these groups, reductions in tort recoveries for failure to mitigate may constitute an undue interference with religious freedom.

The two responses to this issue in past cases may, for convenience, be labeled the "objective" and "case-by-case" approaches. The objective rule is exemplified by a series of workmen's compensation cases that have held that religion may not justify an otherwise unreasonable failure to obtain medical treatment. ${ }^{5}$ These decisions have justified denial or reduction of compensation awards by adhering to the general tort principle that, in judging conduct by the standard of the "reasonable man," the subjective beliefs of the actor should not be considered. ${ }^{6}$

The case-by-case approach represents an attempted accommodation

Rogerson, Millions Now Living Will Never Die 186-87 (1969). Jehovah's Witnesses sometimes claim that transfusions are not medically beneficial, idl. at 187; their main concern, however, is spiritual since they believe that "prolonging their life by accepting a blood transfusion is a direct sin against God and jeopardizes their prospects of eternal life." Id.

5. E.g., Martin v. Industrial Accident Comm'n, 147 Cal. App. 2d 137, 138-39, 143, 304 P.2d 828, 829, 831 (Dist. Ct. App. 1956) (death benefits denied to family of Jehovah's Witness who refused transfusions during spleen operation); Marlar v. Rosenberg Bros., 20 Cal. Indus. Accident Comm'n 35, 35 (1934) (Christian Scientist refused surgery on fractured wrist); Industrial Comm'n v. Vigil, 150 Colo. 356, 361, 373 P.2d 308, 311 (1962) (refusal to undergo surgery); Walter Nashert \& Sons v. MicCann, 460 P.2d 941, 943 (Okla. 1969) (failure to take heart medications). But cf. Swan v. Walnut Grove Creamery Co., 10 Cal. Indus. Accident Comm'n 126, 126 (1923) (employee who used exclusively Christian Science methods to treat burn given full recovery because of lack of evidence that such methods delayed return to work).

At least with respect to deliberate decisions by an injured person to forgo medical care, the statutory workmen's compensation rules resemble common law tort principles. Ludlam, Plaintiff's Duty to Minimize Defendant's Liability by Surgery, 17 TENN. L. Rev. 821, 821-24 (1943) (two rules are similar, although tort places slightly greater burden on injured plaintiff). Reasonableness remains the determining factor. I A. LARson, THE LAw OF WorkMEN's Compensation \$ 13.22, at 3-398 (7th ed. 1978); W. Malone \& M. Plant, CASEs ANd MAterials on Workmen's Compensation 363-65 (1963) (citing cases and statutes). Except as indicated, it will be assumed in this Note that the duties imposed on injured persons by tort and workmen's compensation law present comparable constitutional problems.

Some states have provided statutory exemptions for Christian Scientists by permitting them to recover compensation if they aroid medical treatment. E.g., Wis. STAr. ANN. $\$ 102.42(1)$, (5), (i) (West 1973 \& Supp. 1977-78) (employee may choose Christian Science treatment unless employer has filed notice of decision not to pay for such treatment); see John, Recognition of Christian Science Treatment, INs. L.J., Jan. 1963, at 19.

6. E.g., Walter Nashert \&. Sons v. McCann, 460 P.2d 941, 943 (Okla. 1969) (compensation cannot be increased if reasonable care is refused on religious grounds); Ash v. Barker, 2 Cal. Indus. Accident Comm'n 40, 45 (1915) (if symptoms indicate need for surgery, refusal based on Christian Science beliefs cannot be held "reasonable" as statute uses term). See Restatement (Second) of Torts $\$ 283$, Comment $c$, at 12 (1965) (standard of conduct "must be an objective and external one, rather than that of the individual judgment, good or bad, of the particular individual").

Presumably, in cases involving serious injuries, an objective standard of reasonableness would generally lead courts to require plaintiffs to obtain medical care. But see John, supra note 5, at 20 (argument that results of Christian Science treatment warrant acceptance of it as reasonable alternative to medical care). 
of this general principle with the rights of religious plaintiffs under the free exercise clause. ${ }^{7}$ In the leading case of Lange $v$. Hoyt, ${ }^{8}$ for example, the court applied the reasonable man standard, but instructed the jury to treat the plaintiff's Christian Science beliefs as a relevant factor in its assessment of her mitigation efforts. ${ }^{9}$

Neither of these approaches adequately accommodates First Amendment principles. Although the objective approach serves valid secular purposes $^{10}$ and applies only incidentally to religious beliefs, it burdens religious practices in a manner proscribed by the free exercise clause. The case-by-case approach may alleviate this burden in some instances, but it violates the establishment clause ${ }^{11}$ because it requires each court to assess the reasonableness of religiously motivated conduct. A partial exemption from the mitigation rule, therefore, is necessary for plaintiffs with religious beliefs about medical care; they should be required to mitigate damages only by methods that do not violate those beliefs.

\section{The Objective Rule and Free Exercise}

Two Supreme Court cases provide the framework for analyzing the free exercise issues presented by the objective mitigation rule. Sherbert v. Verner ${ }^{12}$ and Wisconsin v. Yoder ${ }^{13}$ each created exemptions for citizens whose free exercise was burdened by a neutral state law. In Sherbert a Seventh Day Adventist was denied state unemployment benefits when she refused, because of her beliefs about the Sabbath, to accept a job requiring work on Saturdays. ${ }^{14}$ Although the South Carolina courts upheld this denial of benefits, ${ }^{15}$ the Supreme Court reversed, calling it an impermissible burden on free exercise. ${ }^{16}$ In Yoder Amish parents were exempted from state laws requiring them to send their children to public high schools. ${ }^{17}$

7. U.S. CoNsT. amend. I ("Congress shall make no law ... prohibiting the free exercise of religion").

8. 114 Conn. 590,159 A. 575 (1932).

9. Id. at 596-97, 159 A. at 577-78; accord, Christiansen v. Hollings, 44 Cal. App. 2d 332, 346, 112 P.2d 723, 730 (Dist. Ct. App. 1941) ("[I]f the injured party is a believer in Christian Science, the jury should be instructed ... that such belief is a factor to be considered ... in determining whether the injured person used reasonable diligence.")

10. See pp. 1478-79 infra.

11. U.S. Const. amend. I ("Congress shall make no law respecting an establishment of religion").

12. 374 U.S. 398 (1963).

13. 406 U.S. 205 (1972).

14. 374 U.S. at $399-401$.

15. Sherbert v. Verner, 240 S.C. 286 , 125 S.E.2d 737 (1962), rev'd, 374 U.S. 398 (1963).

16. 374 U.S. at 402 . The Court held that "to condition the availability of benefits upon this appellant's willingness to violate a cardinal principle of her religious faith effectivcly penalizes the free exercise of her constitutional liberties." Id. at 406.

17. 406 U.S. at 207. 
These cases suggest a two-step analysis of the legitimacy, under the free exercise clause, of the objective mitigation rule. ${ }^{18}$ First, it must be determined whether application of the rule against religious tort plaintiffs can be said to burden free exercise. ${ }^{19}$ If such a burden exists, the rule can only be retained if the state can demonstrate a compelling interest in its enforcement. ${ }^{20}$ Despite its apparent simplicity, this test is difficult to apply because the concepts "burden" and "compelling state interest" are poorly defined by the existing case law. ${ }^{21}$

\section{A. The Burden}

In Sherbert and cases in analogous areas, it was established that if a state benefit is conditioned on the abandonment of one's rights, the result may be an unconstitutional burden on personal freedoms. ${ }^{22} \mathrm{~A}$ state benefit burdens free exercise if it is conditioned on conduct prohibited by religious beliefs and if its effect is comparable to that of a law requiring the conduct directly. ${ }^{23}$

When a plaintiff's religious beliefs forbid medical care, the objective mitigation rule imposes a condition on the receipt of a state benefit that exerts pressure on him to relinquish his religious convictions. The

18. The main arguments in Sherbert and Yoder were premised on assumptions that the beliefs involved were both sincere and religious. Wisconsin v. Yoder, 406 U.S. 205, 209, 216 (1972); Sherbert v. Verner, 374 U.S. 398, 399 n.I (1963). This initial issuewhether the plaintiff's beliefs are sincere and religious-would be unlikely to present difficulties in cases involving a free exercise claim by a religious plaintiff who has been penalized for a failure to mitigate. Most such plaintiffs will be able to demonstrate the religious nature of their beliefs by relating them to theological doctrines of recognized religious groups. They will also be able to demonstrate their sincerity by linking their postaccident actions with past patterns of behavior indicating adherence to these religious precepts.

19. Wisconsin v. Yoder, 406 U.S. 205, 218-19 (1972); Sherbert v. Verner, 374 U.S. 398, 403 (1963).

20. Wisconsin v. Yoder, 406 U.S. 205, 215 (1972) (only "interests of the highest order" can justify burdens on free exercise); Sherbert v. Verner, 374 U.S. 398, 406 (1963).

21. Cf. Dodge, The Free Exercise of Religion: $A$ Sociological Approach, 67 Mich. L. REv. 679, 687 (1969) (free exercise case law needs to define further relevant individual and state interests).

22. Sherbert v. Verner, 374 U.S. 398, $404-06$ (1963). See also Shapiro v. Thompson, 394 U.S. 618, 697, 634 (1969) (one-year waiting period for welfare imposed on new state residents conditions benefits on abandonment of right to change residence); Speiser $v$. Randall, 357 U.S. 513, 518 (1958) (tax exemptions conditioned on loyalty oath restrain free spech); 'T. Emerson, The System of Freedom of Expression 191-96 (1970) (citing cases). Bul see Wyman v. James, 400 U.S. 309,324 (197I) (welfare benefits may be conditioned on allowing state employees to enter home).

23. See Sherbert v. Verner, 374 U.S. 398, 404 (1963) (law burdens free exercise "as would a fine imposed against appcllant for her Saturday worship"); Note, Freedom of Religion and Science Instruclion in Public Schools, 87 YALE L.J. 515, 528-30 (1978) (benefit is unconstitutional if conditioned on conduct that state could not require directly because forbidden by religious beliefs and if benefit is effectively equivalent to requiring that conduct). 
state benefit, full compensation for injuries suffered, ${ }^{24}$ is conditioned on compliance with the duty to mitigate. Mitigation of damages is defined by the objective rule to include acceptance of medical treatment despite religious beliefs to the contrary. Under this rule, a plaintiff who abandons his beliefs and accepts medical care does not necessarily increase the compensation he receives for his injury, ${ }^{25}$ but he may eliminate the disparity between that sum and his existing injuries. ${ }^{26}$

\section{Assessing the Burden}

The conditions imposed by the tort recovery process will not burden free exercise unless they create substantial pressure on potential plaintiffs to violate their beliefs. ${ }^{27}$ Sherbert provides few guidelines for identifying those situations in which a burden exists, ${ }^{28}$ but examination of a number of other conditional benefit cases suggests three relevant criteria. ${ }^{29}$ First, the benefit must be important. Second, the benefit must not merely equalize the treatment of religious and nonreligious citizens. Third, the benefit must be likely, as an empirical

24. See Lee v. Southern Home Sites Corp., 429 F.2d 290, 293 (5th Cir. 1970) (purpose of damages is to put plaintiff in his original position by compensating for all injuries actually suffered); Drayton v. Jiffee Chem. Corp., 395 F. Supp. 1081, 1096 (N.D. Ohio 1975) (in any action involving damages, objective is to compensate victim and make him whole); W. Prosser, supra note 2, $\$ 2$, at 7 (purpose of tort action is to compensate victim for damage he has suffered).

25. If it is assumed that courts are able to determine accurately the aggravation of existing injuries that has resulted from a refusal of medical care in a given case, then the dollar amount of a plaintiff's compensation for injuries suffered will be the same whether or not he chooses to obtain such care. The plaintiff who obtains medical care would, however, receive additional damages as reimbursement for the medical expenses incurred.

26. The pressure that the tort system may exert on those with beliefs about medical treatment must be considered the product of "state action." The pressure results from a right of recovery created by the state to serve its goals, such as compensation, justice, and deterrence. See $2 \mathrm{~F}$. HARPER \& F. JAMEs, supra note 2 , \$ 11.5 , at 743 (listing objectives of tort law); cf. New York Times Co. v. Sullivan, 376 U.S. 254, 265 (1964) (state action is present in libel case, even though "law has been applied in a civil action and ... it is common law only, though supplemented by statute"). In addition, the benefit of full compensation is actually denied only by official court action. Cf. Hosey $v$. Club Van Cortlandt, 299 F. Supp. 501, 505-06 (S.D.N.Y. 1969) (holding that Constitution forbids state enforcement of eviction by private landlord in retaliation for exercise of First Amendment rights on theory that court action cannot support private burdens on such rights).

27. See Note, supra note 23 , at 530 .

28. The Sherbert decision deals with the burden question in rather conclusory fashion. The Court stated that the plaintiff could choose either to follow her Sabbatarian beliefs and forfeit unemployment compensation, or to accept work and abandon her faith. Then it simply concluded that the imposition of this choice puts the same burden on free exercise "as would a fine imposed against appellant for her Saturday worship." 374 U.S. at 404.

29. E.g., Johnson v. Robison, 415 U.S. 361 (1974); Shapiro v. Thompson, 394 U.S. 618 (1969); Torcaso v. Watkins, 367 U.S. 488 (1961). 
matter, to motivate a potential beneficiary to take the actions allegedly being encouraged.

Precedent indicates that a state benefit will be important to a person if it provides a portion of his basic livelihood ${ }^{30}$ or creates a substantial opportunity for greater wealth and status. ${ }^{* 1}$ Sherbert, for example, involved the benefit of unemployment compensation. ${ }^{32}$ Cases involving constitutional rights other than free exercise have recognized the pressures created by conditional grants of welfare, ${ }^{33}$ public housing, ${ }^{34}$ public office, ${ }^{35}$ admission to the $b^{3 r},^{36}$ and driver's licenses. ${ }^{3 \tau}$

As Johnson v. Robison ${ }^{38}$ demonstrates, however, even an important conditional benefit will not create a constitutionally significant burden if it merely equalizes the position of religious and nonreligious people. In that case, a conscientious objector sought to receive veterans' education benefits by arguing that these benefits were unconstitutionally conditioned on service in the military, an activity prohibited by his religion. ${ }^{39}$ The Supreme Court, denying his claim, called the burden "incidental" at best ${ }^{40}$ and noted that the benefits were intended by Congress as compensation for the "peculiar rigors of military service." 41

The Robison Court did not attempt to minimize the value in our society of educational opportunity. Instead, its holding reflects an attempt to assess the relative benefits and burdens of military and

30. E.g., Shapiro v. Thompson, 394 U.S. 618, 627 (1969) (welfare benefits conditioned on one-year residency).

31. E.g., Baird v. State Bar, 401 U.S. 1, 6-8 (1971) (grant of admission to bar conditioned on answering questions regarding membership in Communist organizations).

32. 374 U.S. at $399-401$.

33. Shapiro v. Thompson, 394 U.S. 618, 627, 634 (1969) (one-year waiting period for new residents burdens right to change residence).

34. Thorpe v. Housing Auth., 386 U.S. 670, 678-79 (1967) (Douglas, J., concurring) (occupancy of public housing cannot be conditioned on sacrifice of rights of association).

35. Torcaso s. Watkins, 367 C.S. 488, 495-96 (1961) (state cannot coerce declarations of religious faith by oaths recuired of public officeholders).

36. Sperack v. Klein, 385 U.S. 511, 514-16 (1967) (privilege against self-incrimination should not be "watered down" by allowing disbarment as penalty).

37. Bell v. Burson, 402 U.S. 535, 539 (197I) (because driver's licenses "may becomc essential in the pursuit of a livelihood," state cannot require drivers to give up procedural due process rights in order to obtain such licenses).

38. 415 U.S. 361 (1974).

39. Id. at 383 .

40. Id. at 385 .

41. Id. at 385 n.19. It should be noted that in addition to concluding that the law imposed little or no burden on Robison's free exercise, the Court in Robison argued that even a significant burden could be justified in this setting by the government's interest in protecting the nation. Id. at 383-85. It relied on Gillette v. United States, 401 U.S. 437 (1971), a case that upheld the much greater burden imposed by the draft system on conscientious objectors to particular wars who must choose to accept induction, to go to jail, or to become fugitives. Thus a detailed analysis of the extent of the burden imposed in Robison was not essential to the outcome and was not undertaken by the Court. 
alternative service. ${ }^{42}$ Read in this light, the Court's opinion suggests that where the state has created a religious exemption from performance of civic duties by requiring service in alternative, religiously acceptable ways, it need only ensure that the overall "package" of duties and benefits entailed by the religiously acceptable option be no more onerous that the duties and benefits of the other choice. ${ }^{43}$ When Congress allowed conscientious objectors the option of performing alternative national service, it could constitutionally equalize the overall choice presented by giving some additional benefits to those who, by military service, risked life and suffered isolation from civilian life.44

A final consideration in assessing the constitutionality of a conditional benefit, not yet fully recognized by the courts, is the degree to which the conditions imposed are likely to create pressure on an individual to alter his conduct in order to qualify. If, in practice, no such pressure exists, then no burden results. ${ }^{4 \bar{j}}$ This factual assessment requires weighing the various considerations that would contribute to an individual's decision to seek the benefit. For example, Robison might be interpreted as a case where the Court simply concluded that veterans' education benefits are seldom an important factor in the decisions of potential draftees about whether or not to seek conscientious objector status. ${ }^{40}$

\section{The Burden of the Objective Rule}

These three criteria, when applied to the plight of a tort plaintiff objecting to medical care for religious reasons, lead to the conclusion that the objective rule does impose a significant burden on free exercise. The benefit involved, full compensation for personal injury, is certainly important. By compensating for lost earnings, pain and suffering, and

42. See Clark, Guidelines for the Free Exercise Clause, 83 HARv. L. REv. 327, 348-54 (1969) (alternative burdens may be imposed on conscientious objectors), ciled at Johnson v. Robison, 41 j U.S. 361,385 n.19 (1974).

43. The Court in Robison did not attempt to make an exact comparison of the dutics and benefits of draftees and conscientious objectors. Such comparisons appear to be beyond judicial competence. See United States v. Boardman, 419 F.2d 110, 113 (Ist Cir. 1969), cert. denied, 397 U.S. 991 (1970) (in case challenging civilian work requirement for conscientious objectors, court will defer to legislative judgment concerning exact balance struck between conscience and needs of state).

44. See Clark, supra note 42, at 348-54.

45. See, e.g., Walsh v. Louisiana High School Athletic Ass'n, 428 F. Supp. 1261, 1268-69 (E.D. La. 1977) (restrictions on athletic participation of transfers to religious high schools held to have only minimal or insignificant impact on free exercise).

46. See 415 U.S. at 385 ("The challenged legislation ... does not require appellee and his class to make any choice comparable to that required of the petitioners in Gilletle.") See note 41 supra. 
medical expenses, ${ }^{47}$ tort damages affected by the mitigation rule can constitute a large part of a plaintiff's livelihood. ${ }^{48}$

The objective rule cannot be explained as an effort to equalize the positions of plaintiffs with and without religious scruples about medical care. Since the government has not previously provided any exemption for the religious in tort law, the burden imposed by the objective rule in fact places plaintiffs with religious scruples at an overall disadvantage. Both classes of plaintiffs have injuries and expenses for which they seek compensation; the rule denies full compensation to those whose mitigation efforts are affected by religious beliefs.

Whether there exists an empirical likelihood that the objective rule places pressure on a plaintiff's decisions concerning adherence to religious practices is more problematic. It may be that potential plaintiffs do not perceive the connection between tort recovery and their religious persuasions when they decide on treatment, or it may be that factors other than liability rules control their choices. General jury verdicts, by cloaking the calculus of damages, may leave in doubt the extent to which the rule is actually applied to penalize religiously motivated conduct. ${ }^{49}$ Even a well-established past pattern of penalties may not influence potential plaintiffs when they are choosing to forgo or accept medical care; a possible lawsuit may be too remote a factor.

These conjectures concerning the possible de minimis impact of the objective rule do not, however, withstand close scrutiny. One may question at the outset whether a state-imposed religious burden may be upheld merely because it is "hidden" from the unwary citizen; such a burden might implicate the establishment clause.50 Furthermore,

47. 2 F. HARPER \& F. JAMEs, supra note 2, at $\$ \S 25.8,25.9,25.10$.

The workmen's compensation system is somewhat different because it gives compensation only for injuries that produce disability and therefore affect earning power. A. LARSON, supra note 5, $\$ 2.40$. Moreover, unlike tort law, the system does not attempt to restore to a claimant all that he has lost through an injury. Id. $\$ 2.50$. Nevertheless, because compensation awards are intended to protect injured workers from destitution, id., they are probably just as important to recipients as most tort recoveries.

48. The conclusion that tort damages denied to religious plaintiffs may be essential to livelihood is not undermined by the ability of some plaintiffs, such as Christian Scientists, to obtain health insurance contracts providing for payment of the costs of treatment in accordance with their religious beliefs. See John, supra note 5, at 20-22. These policies are limited to specific religious groups, and they cover only one component of the costs included in tort recoveries-medical expenses. Id. (policies provide payments for Christian Science practitioners, nurses, and sanitoriums).

49. General jury verdicts produce a single, unexplained damage figure, based on a number of complex, sometimes intuitive, calculations. See 2 F. HARPER \& F. JAMEs, supra note $2, \S 25.1$, at 1301 (compensation in personal injury case will always be "figurative and essentially speculative").

50. Where the state consistently penalizes religious conduct, there may be a constitutional violation regardless of whether the burden is perceived soon enough in each case to affect religious freedom. Such penalties may be barred by the establishment clause. See pp. $1482-83$ infra. 
the effect of the mitigation rule on the recovery will often be apparent. Not all decisions about mitigation are made by juries, ${ }^{51}$ and even many jury verdicts will leave no doubt concerning the extent to which the objective rule has been applied. ${ }^{52}$ The threat to religious plaintiffs consequently is significant.

That threat is likely to produce an awareness by religious plaintiffs of the ramifications of their treatment choices. Members of groups such as the Christian Scientists and the Jehovah's Witnesses are likely to be aware of the legal problems experienced in the past by their fellow members. ${ }^{53}$ In addition, except in unusual cases involving emergency first aid, decisions about treatment may often be preceded by consultations with professionals such as doctors, lawyers, workmen's compensation officials, or even clergymen, ${ }^{54}$ who are presumably knowledgeable about the legal duties of a plaintiff. The burden on free exercise is thus not only substantial, but also apparent to plaintiffs faced with the choice between full compensation and fidelity to religious beliefs.

The conclusion that the objective rule places significant burdens on free exercise is supported by Montgomery $v$. Board of Retirement, ${ }^{55}$ a recent California case involving the denial of a disability pension to a public employee who refused, because of her faith-healing beliefs, to

51. Workmen's compensation disputes are, for example, heard initially by commissions, 1 A. LARSon, supra note $5, \S 1.10$, at 2 , then appealed to the courts.

52. When the mitigation rules reduce a recovery dramatically, the effect will be apparent. E.g., City of Duncan v. Nicholson, 118 Okla. 275, 277, 247 P. 979, 980-81 (1926) (in case without religious issue small damage award was presumed to result from jury's consideration of plaintiff's failure to mitigate). In addition, some juries may be asked to produce special verdicts, explaining their findings on specific issues in the case, including mitigation. E.g., Merrick v. Missouri-Kansas-Texas Ry., 141 Kan. 591, 596-97, 42 P.2d 950, 953 (1935) (in nonreligious case, most of damages awarded by jury must be denied because jury also made special finding of failure to mitigate).

53. These groups are relatively small and tightly knit. The Jehovah's Witnesses have a long history of legal problems that are presumably known to the present members. See, e.g., Fowler v. Rhode Island, 345 U.S. 67 (1953) (exclusion from use of public park for services); Prince v. Massachusetts, 321 U.S. 158 (1944) (restriction on sale of religious literature by children); West Virginia State Bd. of Educ. v. Barnette, 319 U.S. 624 (1943) (compulsory flag salute). See generally American Civil Liberties Union, THe Persecution OF JeHOVAH's WITNESSES (1941).

Christian Scientists have also had numerous, less well-known confrontations with legal authorities. See generally Schneider, Christian Science and the Law: Room for Compromise?, 1 Colum. J.L. \& Soc. Pron. 81 (1965); Steinhardt, Chrislian Science: Religious Freedom and State Control, 7 Mami L.Q. 358 (1953). They are told that they should be the most "law-abiding people on earth" and that it is therefore "essential" for them to "know their legal obligations." Commirree on Punlication, supra note 3, at 7 .

54. In most cases involving mitigation by a religious plaintiff, the factual settings indicate ample opportunity for such consultation. See, e.g., Industrial Comm'n v. Vigil, 150 Colo. 356, 358, 373 P.2d 308, 309 (1962) (refusal of surgery); Walter Nashert \& Sons $v$. McCann, 460 P.2d 941, 942 (Okla. 1969) (refusal to take medication over long period).

55. 33 Cal. App. 3d 447, 109 Cal. Rptr. 181 (Ct. App. 1973). 
undergo surgery that would have restored her ability to work. ${ }^{56}$ The court, relying expressly on Sherbert, held the denial a burden on free exercise. ${ }^{57}$ The choice faced by the employee in Montgomery was analogous to that faced by a potential tort plaintiff with similar beliefs. ${ }^{58}$ In the former case, the employee could return to her work by violating her beliefs or remain disabled without compensation; in the latter, the plaintiff can accept medical care and be fully compensated or follow his beliefs and endure uncompensated injuries. In either situation, free exercise is restrained.

\section{B. The State Interests}

\section{The Compelling Interest Requirement}

Although Sherbert held that the burden created by a conditional benefit may be justified by a compelling state interest, ${ }^{59}$ the case provides few criteria for determining when such a state interest is present. ${ }^{00}$ Courts faced with new cases may choose either to uphold almost any free exercise claim, ${ }^{61}$ or to engage in a formless balancing of individual and governmental interests, applying the "compelling" label whenever they decide the state should win.62 The inherent elasticity of the compelling interest standard has been recognized by the Supreme Court. In Yoder, for example, the Court manifested con-

56. Id. at 448-50, 109 Cal. Rptr. at 182-83. Under the terms of the statute governing disability pensions, the denial of benefits depended, not on a finding that the refusal of the surgery was unreasonable, but on a finding that the applicant was not "permanently incapacitated" because surgery could restore her health. Id. at 449, 109 Cal. Rptr. at 183 (discussing CaL. Gov'T CodE $\$ 31720$ (West 1968)). This difference in the legal standard for denying the benefit does not, however, affect the significance of the burden created when the benefit is in fact denied.

57. Id. at 451,109 Cal. Rptr. at 184 .

58. Id. at 453,109 Cal. Rptr. at 186 (declining to follow Martin v. Industrial Accident Comm'n, 147 Cal. App. 2d 137, 304 P.2d 828 (Dist. Ct. App. 1956), which upheld denial of workmen's compensation benefits to employees who refuse medical care on religious grounds, because the "ratio decidendi of the case is inconsistent with and cannot be reconciled with the rules laid down in ... [Sherbert]").

59. Sherbert v. Verner, 374 U.S. 398,406 (1963).

60. See note 21 supra.

61. Cf. L. Pfeffer, God, Caesar and the Constiturion 36 (1975) (compelling interest test affords nearly absolute protection to religious exercise).

62. See Clark, supra note 42 , at 330 (courts need more specific guidelines for dealing with free exercise cases); 18 VILc. L. REv. 955, 967 (1973) (weighing of state interests in Yoder fails to enlighten future courts about how decisions should be made). "Ad hoc balancing" of interests can be criticized on two grounds. First, it increases the danger that courts will defer too often to legislative judgments and fail to protect First Amendment rights adequately. T. Emerson, Toward a General Theory of the First AmendMENT 55 (1967); Clark, supra note 42, at 330. Second, it represents adjudication undertaken in the absence of neutral standards. Marcus, The Forum of Conscience: Applying Slandards under the Free Exercise Clause, 1973 Duke L.J. 1217, 1240. 
cern over the need for a more specific definition of compelling interest by attempting to find less conclusory synonyms, although its best effort-"interests of the highest order" 63 -indicates that the attempt to achieve clarity fell short of success.

In the free speech area, the Court's efforts to clarify compelling interest analysis have been more fruitful. In United States $v . O^{\prime}$ Brien $^{64}$ a case involving a conviction for draft card burning, the Court noted the various ways in which earlier cases had described the state interest required to justify incidental interference with expression: "compelling; substantial; subordinating; paramount; cogent; strong:" ${ }_{05}$ The Court continued:

Whatever imprecision inheres in these terms, we think it clear that a government regulation is sufficiently justified if it is within the constitutional power of the Government; if it furthers an important or substantial governmental interest; if the governmental interest is unrelated to the suppression of free expression; and if the incidental restriction on alleged First Amendment freedoms is no greater than is essential to the furtherance of that interest. ${ }^{60}$

The Court's language indicates that the $O$ 'Brien test might reasonably apply to regulation of free exercise as well as free speech, ${ }^{07}$ and at least one subsequent case lends indirect support to this extension. ${ }^{68}$

Consequently, one way to decide whether a conditional benefit burdening free exercise is constitutional is to evaluate the state interest behind the benefit according to the four O'Brien criteria.$^{60}$ The first

63. Wisconsin v. Yoder, 406 U.S. 205, 215 (1972). Because the Court cited Sherbert at this point, $i d$., it is apparent that the new language used in Yoder was not intended to represent a new substantive standard for free exercise cases. Note, supra note 23, at 540 n.121.

64. 391 U.S. 367 (1968).

65. Id. at $376-77$.

66. Id. at 377 .

67. O'Brien cited Sherbert in its reforences to past compelling interest cases, id. at $376 \mathrm{n} .22,377 \mathrm{n} .27$, and the $O^{\prime} B r i e n$ test itself refers generally to "First Amendment freedoms." $I d$. at 377 . The facts involved in $O^{\prime} B r i e n$ were similar in many way to those at issue in Sherbert and other free exercise cases. Like the unemployment laws in Sherbert, the draft laws under which O'Brien was convicted did not appear to implicate First Amendment freedoms. Nevertheless, they caused "incidental" burdens on expression because certain individuals chose to express their beliefs by conduct contrary to the statttory directives. Id. at 376. O'Brien did involve a direct prohibition, rather than a conditional benefit, but the exact nature of the burden on First Amendment freedoms should not alter the analysis applied in assessing the countervailing state interests.

68 . Wooley v. Maynard, 430 U.S. 705,716 (1977) (O'Brien test applied in case involving restraints on religiously motivated expression).

69. This approach is inapplicable to cases where a neutral state law affects ancillary activities of a religious group that are not themselves practices required by religion. A compelling state interest is not required in such instances. See King's Garden, Inc. v. FCC, 498 F.2d 51, 59-61 (D.C. Cir.), cert. denied, 419 U.S. 996 (1974) (FCC antibias regulations 
criterion, requiring that the law be within the constitutional power of government, actually poses a separate issue. First Amendment inquiry would be unnecessary if the law were invalid for this more general reason..$^{70}$ Although some commentators have considered the second criterion, that the law further an important or substantial state interest, to be insignificant, ${ }^{71}$ it does place certain restrictions on a state's actions. If the interest justifying a burden on free exercise must be "substantial," one kind of state interest is excluded-administrative efficiency. ${ }^{72}$ In addition, the substantial interest must be "further[ed]": the law must be likely to contribute directly to the state's announced goal. ${ }^{73}$

The third criterion in O'Brien, requiring that the governmental interest be unrelated to the suppression of expression, is intended to invalidate laws that burden First Amendment freedoms intentionally rather than merely incidentally. This criterion implies that religious conduct may not be restricted either because it is not favored by the government or because the beliefs it reflects are thought to be dangerous. $^{74}$ This analytic step may play a key role in some cases, ${ }^{75}$ but carries no force when the law at issue is assumed to be a secular regulation that creates only unintended burdens on free exercise. ${ }^{76}$

The first three O'Brien standards provide little free exercise protection from secular regulations because they would validate most laws regardless of the severity of the burdens they imposed. The key criterion is the fourth one, which requires that incidental burdens on First

do not inhibit religious exercise or expression when applied to hiring by religious radio station of employces for jobs unconnected with espousal of religious doctrine; Yoder is "inapposite"); Meyers v. Southwest Region Conf. Ass'n of Seventh Day Adventists, 230 La. 310, 323, 88 So. 2d 381, 386 (1956) (workmen's compensation laws apply to churches as employers); Allendale Congregation of Jehovah's Witnesses v. Grosman, 30 N.J. 273, 277-80, 152 A.2d 569, 571-72 (1959), appeal dismissed, 361 U.S. 536 (1960) (zoning regulation requiring church to provide off-street parking is reasonable and therefore constitutional).

70. Cf. Ely, Flag Desecration: A Case Study in the Roles of Categorization and Balancing in First Amendment Analysis, 88 HaRv. L. Rev. 1482, 1483 n.10 (1975) (constitutional power test is "superfluous").

71. E.g., id. at 1485-86 (important state interest test has "trivial functional significance").

72. See Note, The Religious Rights of the Incarcerated, 125 U. PA. L. REv. 812, 865-66 (1977) (citing cases) ("economy" and "convenience" generally denied compelling interest status by Supreme Court).

73. Cf. Ely, supra note 70, at 1486 n.17 (littering regulations could ultimately be linked to quality of life and even to survival of planet); Note, Symbolic Conduct, 68 Colus. L. REv. 1091, 1102 (1968) (O'Brien Court failed to recognize "remote and speculative" nature of state interests asserted and fact that statute was ill-designed to achieve desired results).

74. A law that burdened a religion because it was disfavored or thought dangerous would be absolutely barred by the establishment clause. See pp. 1482-83 infra.

75. See Ely, supra note 70, at $\mathbf{1 4 9 6 - 9 7}$ (third criterion is "definitive" part of overall test because it distinguishes suspect regulations from less questionable ones).

76. See p. 1468 supra. 
Amendment freedoms be no greater than is essential to the furtherance of the state interest involved. This criterion infuses into First Amendment law what is generally known as a "less restrictive alternative"77 or "less drastic means"78 test. Unfortunately, the method for applying this test has been left ambiguous by the Court. ${ }^{79}$

In order to decide whether the state can achieve its goals in a manner that imposes lesser burdens on religious freedom, the relevant state goals at stake must be analyzed in detail. The less drastic means requirement implicitly assumes that some statutory purposes are insufficient to justify a law burdening constitutional rights. ${ }^{80}$ The third criterion, which invalidates intentional burdens on rights, suggests that one such insufficient purpose is the imposition of a burden for its own sake. In addition, the substantiality requirement in criterion two plays a role here: ${ }^{81}$ if the state's only argument is that an alternative regulation will be administratively less efficient, then it must accept that alternative. ${ }^{82}$ To justify a burden on free exercise, the state must prove that any less restrictive law would fail to achieve a substantial state goal. ${ }^{83}$

\section{Mitigation and Compelling State Interests}

Applying the $O^{\prime} B r i e n$ criteria to the objective mitigation rule requires identification of the state interests served by the mitigation doctrine. Traditional tort theory justifies mitigation requirements in

77. Ely, supra note 70 , at 1484 .

78. Note, Less Drastic Means and the First Amendment, 78 YALE L.J. 464, 473-74 (1969).

79. Ely, supra note 70, at $1484-87$ (test may be interpreted in two ways); Note, supra note 78, at 468 (exact manner in which Court applies test remains uncertain).

80. Otherwise, it would always be possible for the state to argue that a law's purpose is to achieve all of its actual effects. Cf. Note, Legislative Purpose, Rationality, and Equal Protection, 82 YALE L.J. 123, $128-32$ (1972) (statute's purpose can always be defined as burdening or benefiting of identified class, thereby making statute rational in equal protection terms). If such an argument were accepted, only another law with wholly identical effects would constitute a valid less restrictive alternative. Thus there must be some limit on the set of state goals that can justify burdens on First Amendment freedoms. Cf. id. at 138-39 (when courts label statute irrational, they often mean that some of goals it pursues are "impermissible").

81. See Smith v. Goguen, 415 U.S. 566, 599-600 (1974) (Rehnquist, J., dissenting) (important interest test merges with less drastic means test).

82. See p. 1477 supra; Note, supra note 23 , at 542 (state must accept less efficient alternate means as long as state interest still served sufficientiy). Arguably, the Court ruled out administrative efficiency as a justification for a burden on free cxercise in Sherbert when it rejected the state's argument that an exemption for Sabbatarians would lead to an increase in fraudulent claims. 374 U.S. at 407 . See Marcus, supra note 62, at 1242.

83. See Clark, supra note 42 , at 345 (should be rcbuttable presumption that state can achieve its end in alternative ways); Note, supra note 72, at 869. 
"fairness" terms as a mechanism for protecting defendants from liability for additional injuries that, because of a plaintiff's intervening conduct, they did not proximately cause. ${ }^{84}$ More modern theory justifies the requirements as a mechanism for the minimization of accident costs. ${ }^{85}$ Under this view, the mitigation rule places an incentive on the plaintiff to reduce the impact of an accident through medical care, thus preventing needless imposition of expenses on the defendant.

Under either the fairness or the cost avoidance approach to mitigation, the objective rule satisfies the first three O'Brien criteria. The state certainly has the constitutional power to create rules of liability. ${ }^{86}$ In doing so, the state has a substantial interest, unrelated to the suppression of religious exercise, in choosing a mitigation rule that promotes fairness or minimizes the social costs of accidents. ${ }^{87}$

The fourth O'Brien test, the less restrictive alternative requirement, requires a closer examination of the asserted state interests; the particular rule that creates a burden on free exercise must be "essential to the furtherance"ss of those interests. ${ }^{89}$ The issue is whether the state would be unable to achieve its admittedly substantial goals if it adopted a less restrictive rule that allowed some consideration of the religious beliefs of plaintiffs. ${ }^{90}$

Such a modification of the mitigation rule would not significantly diminish the fairness of the state's tort system. Indeed, special treatment for religious plaintiffs may be fully consistent with the fairness principles that underlie the mitigation doctrine, even though the

84. Morro v. Brockett, 109 Conn. 87, 92, 145 A. 659, 661 (1929) (plaintiff's failure to use reasonable care might "inject an intervening cause which would pro tanto render the defendant's act a remote cause"); see Gilbert v. Kennedy, 22 Mich. 117, 132 (1871) (mitigation rule is one of good faith and fair dealing); Colvin v. John Powell \& Co., 163 Neb. $112,133,77$ N.W.2d 900,914 (1956) (damages will be adjusted where, because of failure to mitigate, it is not just to compel defendant to pay full compensation); Walter Nashert \& Sons v. McCann, 460 P.2d 941, 943 (Okla. 1969) (religious claimant will not be permitted to impose unreasonable additional burdens on his employer in practicing his beliefs).

85. C. MCConmick, HandBook oN THE LAW of DAMAGes $\$ 33$, at 127 (1935) (mitigation rule is mechanism to protect and conserve economic welfare of entire community). Cf. G. Calabrest, The Costs of Accidents 26 (1970) (along with preserving justice, main purpose of accident law is to minimize overall accident costs).

86. The development of common law liability rules has been a major function of the state for many centuries. W. Prosser, supra note 2 , at $\$ 7$. These rules now represent an important tool used by government as it responds to the serious "accident problem" in our socicty. 2 F. HARPER \& F. JAMEs, supra note 2 , at $\$ \$ 11.1,11.5$.

87. Cf. Watson v. Employers Liab. Assurance Corp., 348 U.S. 66, 72 (1954) (state has "natural interest" in providing injured citizens with means to recover damages).

88. 391 U.S. at 377.

89. Cf. Wisconsin v. Yoder, 406 U.S. 205, 221 (1972) ("we must searchingly examine" state's asserted interests, rather than accepting "swceping claims").

90. For the present, no distinction is being made between a case-by-case approach to the problem and a full excmption for plaintiffs with beliefs that forbid medical care. For a discussion of the issues raised by that further choice, see pp. 1482-87 infra. 
result may be increased liability for defendants. In numerous instances, tort law recognizes that a plaintiff's preexisting physical and mental characteristics should not operate to deny him full compensation. ${ }^{91}$ Like these other characteristics, religious beliefs can be seen as preexisting features of a plaintiff's makeup that it may be impossible, or at least unfair, to change through financial incentives. ${ }^{92}$ It is arguable that a modification of the mitigation rule to relieve the pressure on religious plaintiffs would actually increase rather than diminish the fairness of the tort system. ${ }^{93}$

A modification of the objective rule to accommodate religion might also improve the cost-minimizing qualities of the system. The duty to mitigate operates to reduce the social impact of accidents by motivating plaintiffs to reduce their injuries. Plaintiffs' mitigation efforts may be judged by means of Judge Learned Hand's definition of reasonable conduct: ${ }^{94}$ they must seek any treatment the cost of which is less than the benefit to be produced, discounted by the likelihood of that benefit. ${ }^{95}$ By penalizing plaintiffs who fail to obtain adequate

91. See, e.g., Snider v. Callahan, 250 F. Supp. 1022, 1023 (W.D. Mo. 1966) (court must weigh subjective abilities of plaintiff in judging contributory negligence by mentally deficient person); Owen v. Dix, 210 Ark. 562, 566, 196 S.W.2d 913, 915 (1946) (plaintiff whose weak spine aggravated injuries will be given full recovery because of "well-settled" rule of full compensation where victim is predisposed to injury). Cf. James \& Dickinson, Accident Proneness and Accident Law, 63 HARv. L. REv. 769, 786-87 (1950) (fault standard should be more subjective for contributory negligence than for actionable negligence). But see Restatement (SECOND) OF ToRTs $\$ 464$ (1965) (consistent standard of reasonable care applies to all plaintiffs except children and perhaps fully insane).

92. See Clark, supra note 42, at 337 (disobedience of law that conflicts with onc's religion is often "inevitable" and in some sense "involuntary"). Religious beliefs can occupy a central position in an individual's personality and may outweigh the influence of external motivating factors. See M. Argyle \& B. Beit-Hallahm, The Social Pyschology OF RELIGION 199-201 (1975) (comparing strength of religious beliefs with obsessions of neurotics); W. Clark, The Psychology of Religion 274-75 (1958) (intensely religious people may have altered views of reality itself that cause them to resist social norms). The point here is not to denigrate religious faith in any way, but to show why it arguably should be treated as a fixed characteristic of the plaintiff, rather than as an "attitude" over which he has control.

93. The "fairness" justification for an objective mitigation rule depends at least in part on the notion that unusually rash or foolish people can and should modify their behavior to conform to societal standards. See W. Prosser, supra note 2, § 32, at 153 (fool "must learn to conform to [community] standards" or pay for harm he causes). Indeed, any moral argument about the "fair dealing" that plaintiffs owe to defendants, see note 84 supra, would appear to assume that the mitigation duty extends only to acts over which the plaintiffs have control. If a religious plaintiff has no real chance to choose between various curative methods because of the restraints imposed by his beliefs, then he cannot be morally condemned.

94. United States v. Carroll Towing Co., 159 F.2d 169, 173 (2d Cir. 1947) (L. Hand, J.) (cost/benefit definition of negligence).

95. Rathborne, Hair \& Ridgway Co. v. Williams, 59 F. Supp. 1, 4 (E.D.S.C. 1945) (mitigation efforts required depend on "extent of the threatened injury as compared with the expense of remedying the situation, and the practical certainty of success in preventive effort”); Mobile \& O.R.R. v. Red Feather Coal Co., 218 Ala. 582, 585, 119 So. 606,609 (1929). 
care after an accident, the state seeks to assure that the accident costs faced by defendants are not unduly exaggerated. ${ }^{96}$

Under the cost avoidance theory, the task of a judge or jury is to determine whether the plaintiff accepted all forms of medical treatment that were justified in cost-benefit terms. The objective rule distorts this determination by excluding from a court's consideration a significant cost of medical care faced by some religious plaintiffs-the cost of violating one's religious beliefs. One aspect of this potentially great, but not easily quantified, cost is the psychological injury suffered by an individual who believes he has violated a divine command. This injury is as real and legitimate as the "pain and suffering" damages that are regularly reflected in tort recoveries. ${ }^{97}$ In addition, society as a whole, which values an individual's freedom to follow his religious faith, may suffer a loss when a person violates his beliefs. ${ }^{98}$ By ignoring this cost, the objective rule leads, in at least some cases, to the imposition of burdens on plaintiffs that are greater than is required by the goal of accident cost reduction. ${ }^{99}$

96. For example, if a plaintiff could cure a $\$ 100$ injury for $\$ 50$ but does not do so because there is no mitigation rule, defendants will spend up to slo0 preventing that injury. In such a situation, efficiency is not served because an accident is avoided by the expensive methods available to defendants, rather than cured by the relatively cheap methods available to the plaintiff. Cf. R. PosNer, Economic Analysis of Law 123-24, $142-43$ (2d ed. 1977) (contributory negligence rule is necessary to produce most efficient cost avoidance; punitive damages, by exaggerating defendants' costs, produce inefficiently high level of investment in prevention).

It might be argued that the incentive created by the mitigation doctrine is unnecessary because people already have enough incentives to obtain medical care. $C f$. Schwartz, Contributory and Comparative Negligence: $A$ Reappraisal, 87 YALE L.J. 697, 710 (1978) (contributory negligence rule may be unnecessary because plaintiff has "first-party" incentives to avoid injuries). But even if this is true, the rule will simply have little effect; plaintiffs will get the appropriate amount of care and defendants will pay for it.

97. 2 F. HARPER \& F. JAMES, supra note 2, at $\$ 25.10$.

98. The existence of the First Amendment itself may be taken as evidence of this social commitment. Even this social cost might be understood in purely utilitarian terms: society may lose something valuable if it restrains the individuality that may generalize into socially productive creativity. See J.S. MiLL, ON LibERTY 67-68 (C. Shields ed. 1956).

99. It is possible, but unlikely, that a modification of the objective rule to allow consideration of religious beliefs would significantly increase overall accident costs by climinating the "spreading" benefits of the rule or creating new administrative problems. See G. Calabresi, supra note 85, at 27-28. Because it denies full compensation to plaintiffs who fail to mitigate, the objective rule does spread the burden of some accidents between plaintiffs and defendants. But such a spreading benefit is inconsequential because it does not impose burdens on anyone except the immediate parties to an accident. Benefits from spreading are significant only when the costs are distributed over a large class, as in insurance schemes or when a manufacturer is held liable for all the defects in his products. $C f$. $i d$. at $279-81$ (comparative negligence rule divides burden but does not spread it because it fails to burden party who can spread loss to others).

The introduction of religious issues into some tort cases is also unlikely to increase dramatically the costs of adjudication. These issues can be tried like any others by the courts. In addition, even if administrative costs did increase, they alone cannot justify a state's failure to discharge its constitutional duty to adopt the less drastic alternative. See p. 1478 supra. 
A modification of the objective rule that allows consideration of religious beliefs would likely further the state's fairness and cost avoidance goals, or at worst still would allow their substantial achievement. Thus as a "less restrictive alternative," such a modification is required.100

\section{Case-by-Case Assessments and the Establishment Clause}

The case-by-case approach ${ }^{101}$ might function as a less restrictive alternative as required by the fourth $O^{\prime} B r i e n$ criterion. It allows courts to give some weight to religious factors. Nevertheless, establishment clause principles make this alternative a highly dubious one, thus indicating the need for a third solution-a partial exemption for plaintiffs with religious beliefs concerning medical care.

\section{A. General Principles}

As the Supreme Court has recognized, the exact dimensions of the establishment concept are difficult to summarize. ${ }^{102}$ It has long been clear, however, that the fundamental mandate of the establishment clause is state neutrality in matters affecting religion. ${ }^{103}$ This requirement has been elaborated into a detailed set of rules applicable to instances of state financial aid to religious organizations. ${ }^{104}$ Although these rules provide some guidance for assessment of the case-by-case mitigation rule, ${ }^{105}$ they must be read in light of the general First

100. The conclusion that the state lacks a compelling interest in the maintenance of the objective rule is supported by a number of cases holding that government may not compel acts forbidden by religious beliefs in order to protect the actor from himself. $S c c$ People v. Woody, 61 Cal. 2d 716, 719-23, 394 P.2d 813, 816-18, 40 Cal. Rptr. 69, 71-74 (1964) (upholding right of peyotist cult to use drug sacramentally); Montgomery v. Board of Retirement, 33 Cal. App. 3d 447, 452, 109 Cal. Rptr. 181, 185 (Ct. App. 1973) (where religious beliefs involved, state interest in preserving health of sane adult "pales into insignificance"); In re Estate of Brooks, 32 IIl. 2d 361, 372-73, 205 N.E.2d 435, 441-42 (1965) (upholding right of adult to refuse life-saving treatments). But see John $\mathrm{F}$. Kennedy Memorial Hosp. v. Heston, 58 N.J. 576, 580, 279 .1.2d 670, 672 (1971) (denying constitutional right to die).

101. See pp. 1467-68 supra.

102. Lemon v. Kurtzman, 403 U.S. 602, 612 (1971).

103. Epperson v. Arkansas, 393 U.S. 97, 104 (1968) (requirement of neutrality among religions and between religion and nonreligion); School Dist. of Abington v. Schempp, 374 U.S. 203, 225 (1963) (establishment clause requires that "the Government maintain strict neutrality, neither aiding nor opposing religion").

104. E.g., Lemon v. Kurtzman, 403 U.S. 602, 612-13 (1971) (statute must have "sccular legislative purpose" and "primary effect . . . that neither advances nor inhibits religion" and must avoid any " excessive government entanglement with religion' " (quoting Walz v. Tax Comm'n, 397 U.S. 664, 674 (1970)).

105. See New York v. Cathedral Academy, 98 S. Ct. 340, 345-46 (1977) ("entanglements" prohibited by Lemon v: Kurtzman, 403 U.S. 602 (1971), include judicial inquiry into implications of course material at religious school; court cannot be "arbiter of the essentially religious dispute"). 
Amendment principle that the state may not judge the validity of particular religious doctrines. ${ }^{106}$ This principle has expanded to prohibit any state pronouncements approving or disapproving particular religions, ${ }^{107}$ on the rationale that such pronouncements will indirectly interfere with freedom of religious choice. ${ }^{108}$

\section{B. Establishment and the Mitigation Rule}

The case-by-case solution creates establishment clause issues because of the danger that it will lead courts to assess religious beliefs. Analysis of these issues will require renewed attention to the distinction between the fairness and cost avoidance theories of mitigation.

Traditionally, tort law has promoted fairness by requiring a jury to assess the reasonableness of the plaintiff's mitigation efforts. A finding of unreasonableness means either that the plaintiff acted without due regard to the severity of his injuries and the need for medical care, or that he acted in defiance of his duty to mitigate, knowing that damages would result. If plaintiffs consciously forgo medical care on religious grounds, their conduct cannot be treated as thoughtless or careless; ${ }^{109}$ instead, the verdict of failure to mitigate must be taken as a statement that the plaintiff's choice was a willful abrogation of legal responsibility. But since the duty to mitigate commands only "rea-

106. United States v. Ballard, 322 U.S. 78, 86 (1944) (truth of religious claims cannot be assessed in fraud prosecution); see United States v. Seeger, 380 U.S. 163, 184-85 (1965) (validity of beliefs held by person seeking conscientious objector status cannot be questioned); Fowler v. Rhode Island, 345 U.S. 67, $69-70$ (1953) (courts may not "approve, disapprove, classify, regulate, or in any manner control sermons delivered at religious meetings"); Founding Church of Scientology v. United States, 409 F.2d 1146, 1156-57 (D.C. Cir.), cert. denied, 396 U.S. 963 (1969) (government officials cannot question curative claims about healing machine that are affirmed as religious doctrine).

Although the courts have seldom been specific about this, the prohibition of judicial assessment of religious beliefs seems to be essentially an establishment clause rule. The courts are absolutely barred from such assessment, even where direct coercion of religious belief has not been shown.

107. See, e.g., Engel v. Vitale, 370 U.S. 421, 436 (1962) (official school prayer held invalid as "governmental endorsement" of religion); Lowe v. City of Eugene, 254 Or. 534, 544, 463 P.2d 360, 363 (1969), appeal dismissed, 397 U.S. 591, cert. denied, 397 U.S. 1042 (1970) (denying rehearing) (cross on public land impermissible because it implies state endorsement of religion). But see Eugene Sand \& Gravel, Inc. v. City of Eugene, 276 Or. 1007, 558 P.2d 338 (1976), cert. denied, 46 U.S.L.W. 3219 (1977) (same cross permissible when called war memorial under city charter amendment). See also Annot., 36 A.L.R.3d 1256 (1971) (citing cases).

108. Engel v. Vitale, 370 U.S. 421, 429 (1962) (Framers knew that placing government "stamp of approval" on some religious practices would threaten religious freedom of (lissenters); see Schwartz, No Imposition of Religion: The Establishment Clause Value, 77 YALE L.J. 692, 720 (1968) (government preference of particular faiths is feared because it will lead to imposition of religion).

109. Indeed, in cases involving faith healers like the Christian Scientists, the plaintiffs believe they are secking the most effective cure for their injuries. See note 3 supra. 
sonable" steps, such a finding implies that the choice not to seek care lacked a rational foundation.

A jury verdict thus penalizing religiously motivated conduct may reflect a conclusion either that such conduct deviates from community norms, ${ }^{110}$ or that the underlying religious beliefs are simply false. ${ }^{111}$ Under either view, the First Amendment is infringed. The latter interpretation directly contravenes the prohibition against judicial assessment of religious doctrine. The former interpretation, by reacting to the statistical prevalence in the population of particular beliefs, results in systematic discrimination against minority groups on the invidious basis of their unpopularity. Such discrimination cannot be reconciled with the requirement of state neutrality in religious matters. ${ }^{112}$

A cost-minimization interpretation might be used to avoid charges of discrimination or judicial assessment of belief. If determining "reasonableness" entails no more than weighing costs and benefits, then arguably inclusion of the psychological cost of violating religious precepts as a factor in the balance does not require a judge or jury to pass on the merit of a plaintiff's convictions. ${ }^{113}$ To avoid discrimination, however, it would be necessary to treat all religious beliefs alike for this purpose by assigning a fixed cost to the act of violating one's beliefs. ${ }^{114}$ Arguably, this interpretation of the case-by-case rule might be justified as a secular regulation that only incidentally benefits some faiths while hindering others. ${ }^{115}$

It is doubtful, however, that a court can segregate the issue of the truth or falsity of a plaintiff's beliefs about medical care from the issue of the efficiency of his mitigation decisions. In judging the costs and benefits of the treatment decisions made by a plaintiff, the judge or jury must compare his actual choices with those he could have made. Even if, in doing so, the court assigns a fixed value to the cost of

110. This interpretation of the verdict would be appropriate if it is assumed that a jury decided what a reasonable man would do by asking what most people in society would do in a given situation.

111. The jury verdict may reflect a decision about the truth of the plaintiff's beliefs because it is arguable that his post-accident conduct is necessarily reasonable if his beliefs are true.

112. See notes 103 supra \& 116 infra.

113. See p. 1481 supra (costs associated with abandoning one's beliefs). This might be a plausible explanation of jury instructions, like those in Lange, which state in effect that religion cannot excuse unreasonable actions but that it should receive some consideration. See p. 1468 supra.

114. An arbitrary value could be assigned to the act of violating any religious beliefs and applied in all cases involving such an act.

115. See McGowan v. Maryland, 366 U.S. 420 (196I) (Sunday closing laws valid for secular purposes despite imposition of differential burdens on some religious groups). 
abandoning strongly held beliefs, it must also determine whether an alternative course of action, involving religiously prohibited treatments, would have cured the plaintiff's injuries more effectively. Thus, at least where faith healing beliefs are involved, the court must still assess the truth of the doctrine that such healing is more effective than medicine.

Furthermore, it is doubtful whether the cost factor, which will necessarily be given an arbitrary value and which cannot be expressed quantitatively, could be applied consistently. There would be no mechanism for assuring the application of the same valuation in all cases. Because jury verdicts tend to depend on factors like jurors' identification with parties to litigation, there would be a danger of discrimination against plaintiffs whose particular beliefs were less wellknown or popular. ${ }^{116}$

In addition, the cost avoidance interpretation is unlikely to portray accurately judicial decisionmaking in this area. The traditional fault language still employed in decisions and jury instructions invites a court to judge whether a plaintiff's actions seem reasonable in the ordinary sense. Finally, the cost avoidance interpretation may lead to verdicts that impose a burden on free exercise similar to that created by the objective rule. ${ }^{117}$ If courts consistently undervalue the im-

116. See H. Kalven \& H. Zeisel, The American Jury 193-94, 217-18 (1966) ("empathy" of jurors with particular defendants is significant factor in verdicts). Christian Scientists, for example, might be favored over other more obscure groups with similar beliefs. Cf. Lange v. Hoyt, 114 Conn. 590, 597, 159 A. 575, 578 (1932) (court cannot disregard curative beliefs held by "large number" of people). It is certainly clear that Christian Scientists have been given treatment not available to other groups through the creation of legislative exemptions specifically for them. See, e.g., note 5 supra (statutory exemptions for Christian Scientists from duty to accept medical care under workmen's compensation); John, supra note 5 , at 19 (citing statutes). Yet the invidious nature of such discrimination is apparent. See Kolbeck v. Kramer, 84 N.J. Super. 569, 576, 202 A.2d 889, 893 (Super. Ct. Law Div. 1964) (invalidating state university regulation exempting from vaccination program Christian Science students but not others with similar beliefs).

A further indication of the inherent danger of discrimination in cases where mitigation by religious plaintiffs is an isste can be seen in cases where plaintiffs, seeking child support payments, have sued doctors or pharmacists for causing pregnancies by their negligence. E.g., Coleman v. Garrison, 327 A.2d 757, 761 (Del. Super. 1974), aff'd, 349 A.2d 8 (Del. 1975) (where plaintiff victim of negligent sterilization operation, court did not require alternatives less costly than raising child); Troppi v. Scarf, 31 Mich. App. 240, 258 n.11, 260, 187 N.W.2d 511, 519 n.11, 520 (Ct. App. 1971) (where tranquilizers dispensed instead of birth control pills plaintiff not required to have abortion or place child for adoption; effect of religious scruples acknowledged as factor in decision). Although a strong argument can be made in these situations for an abortion as an inexpensive, safe, and relatively easy way to mitigate damages, no court has yet been persuaded to requite this form of mitigation.

117. See pp. 1472-75 supra. Because the establishment clause and the free exercise clause work in the same direction in this situation, this establishment argument is not open to criticism as an overly "wooden" or inflexible example of constitutional analysis. Cf. Sherbert v. Verner, 374 U.S. 398, 414 (1963) (Stewart, J., concurring in result) (to deny 
portance of religious convictions, individuals will continue to feel pressured by the mitigation rule toward abandonment of their beliefs.

\section{Exemption as a Solution}

Because the objective rule burdens free exercise unjustifiably and the case-by-case alternative to that rule runs afoul of the establishment clause, the only interpretation of the mitigation doctrine that accommodates all First Amendment concerns entails a limited exemption from mitigation duties for plaintiffs who have religious beliefs concerning medical care. They should be required to pursue only those "reasonable" curative methods that do not violate their religious convictions. These convictions would operate as constraints that restrict the alternatives available to the "reasonable man" in the plaintiff's position.

In implementing this proposed exemption, the courts should accept a plaintiff's religious beliefs as stated by him, although his sincerity would still be open to question. ${ }^{118}$ Rather than allow a jury to hear evidence about religious beliefs and to draw their own conclusions, it would be preferable to minimize the danger of hidden discrimination by giving to the judge the task of hearing this evidence and presenting his conclusions to the jury as established facts. ${ }^{119}$

This proposed exemption would impose additional financial burdens on defendants to protect the religious freedom of plaintiffs. In this respect, it differs from most religious exemptions, which impose burdens on the state. ${ }^{120}$ There is, however, authority for the proposition that such a particularized burden may be legislatively imposed.121

religious exemption on basis of establishment clause would be to apply clause in wooden manner). This is not a case where the establishment clause is being used to thwart an effort by the state to accommodate religious cxercise.

118. The Court has recognized that assessments of the sincerity of religious claims are sometimes necessary and permissible. E.g., United States v. Seeger, 380 U.S. 163, 185 (1965); United States v. Ballard, 322 U.S. 78, 84-86 (1944).

119. See p. 1485 supra. It could be argued that juries may make decisions in cases involving religion that the state could not make openly. Cf. Clark, supra note 42, at 352 (when juries judge sincerity of beliefs, they can aid state by looking at reasonableness of beliefs and weighing countervailing state interests); White, Processing Conscientious $O b$. jector Claims: $A$ Constitutional Inquiry, 56 CALIF. L. REv. 652, 672 (1968) (jury is best institution to make conclusory judgment in sensitive area of sincerity of conscientious objector claims). Because juries are likely to be less careful about constitutional rights, however, their role should be minimized. Cf. Monaghan, First Amendment "Due Process," 83 Harv. L. Rev. 518, 526-30 (1970) (argument that "any cxpansive conception of the jury's role is inconsistent with a vigorous application of the first amendment").

120. E.g., Sherbert v. Verner, 374 U.S. 398 (1963) (additional unemployment compensation that is paid because of exemption comes from state fisc).

121. Cummins v. Parker Seal Co., 516 F.2d 544 (6th Cir. 1975), aff'd by an equally divided Court, 433 U.S. 903 (1976) (upholding civil rights statutory requirement of ac- 
For example, the courts have upheld federal civil rights laws that require employers to make reasonable efforts to accommodate the religious beliefs of their employees. ${ }^{122}$ There is no reason to believe that the judiciary, in its role as interpreter of common law liability rules, lacks the same power to allocate the costs of protecting constitutional rights.

An exemption for plaintiffs with beliefs about medical care would not significantly impair the state's pursuit of its goals through tort law; it might even advance those goals. ${ }^{123}$ This simple device would eliminate a substantial burden on religious freedom while avoiding the many constitutional complications involved in any less absolute solution.

commodation even where Sabbatarian employee's special exemption caused complaints and required other employees to work extra time on weekends); see Trans World Airlines, Inc. v. Hardison, 432 U.S. 63 (197i) (accommodation rule upheld, although employer made adequate efforts in this case); cf. Note, supra note 23, at $552-53$ (establishment clause does not prohibit accommodations that affect particular other citizens).

The conscientious objector provisions in the selective service statutes have continually been upheld against claims that they violate the establishment clause, e.g., Gillette v. United States, 401 U.S. 437 (1971), even though it could be argued that this accommodation of religion also imposes a severe burden on other citizens-those additional men who must be drafted to serve because religious men have been exempted.

122. See note 121 supra.

123. See pp. 1479-82 supra. 